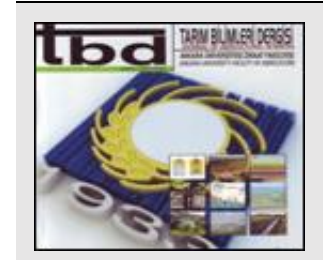

Tarım Bilimleri Dergisi Tar. Bil. Der.

Dergi web sayfası: www.agri.ankara.edu.tr/dergi
Journal of Agricultural Sciences

Journal homepage:

www.agri.ankara.edu.tr/journal

\title{
Effects of Marigold (Tagetes erecta) and Synthetic Carotenoid on Growth Performance and Skin Coloration of Blue Streak Hap (Labidochromis caeruleus) and Pindani (Pseudotropheus socolofi) Fry (Cichlidae)
}

\author{
Nuran CAVDAR ${ }^{a}$, Mevlut AKTAS ${ }^{a}$, Ercument GENC $^{b}$

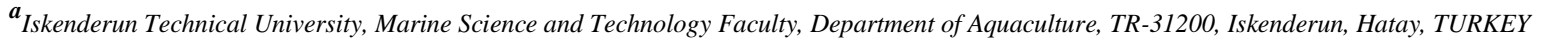

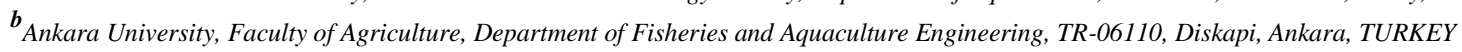

\author{
ARTICLE INFO \\ Research Article \\ Corresponding Author: Nuran CAVDAR, E-mail: nurncavdar@gmail.com, Tel: +90 (312) 5961074 \\ Received: 06 February 2019, Received in Revised Form: 03 April 2019, Accepted: 01 May 2019
}

AUTHORS ORCID ID:

(Nuran CAVDAR: 0000-0001-7079-7148), (Mevlut AKTAS: 0000-0002-7851-0014), (Ercument GENC: 0000-0001-7474-2208)

\begin{abstract}
This study was designed to determine the ideal dosages of marigold (Tagetes erecta) and synthetic carotenoid in blue streak hap (Labidochromis caeruleus) and pindani (Pseudotropheus socolofi) fry (Cichlidae), and to compare effects on the growth and skin coloration. In the first experiment, the blue streak hap and pindani fry fed with different levels of water-soluble marigold flower meal $(0,2$, $4,6,8,10$ and $12 \%$ ) were tested for 30 days to find the optimum skin coloration and growth parameters. Then, in the experiment, the most effective doses of water-soluble marigold flower meal $(2,4,8 \%)$ which obtained from the first experiment were compared with the
\end{abstract}

different synthetic carotenoid dosages (50, 100 and $150 \mathrm{mg} \mathrm{kg}^{-1}$ ) for 30 days. At the end of the first experiment, weight gain and the skin coloration degrees for both fish species were increased significantly by supplementation of $4 \%$ water-soluble marigold flower meal supplemented diet $(\mathrm{P}<0.05)$. In the second experiment, 50 and 100 $\mathrm{mg} \mathrm{kg}{ }^{-1}$ of synthetic carotenoid and $4 \%$ water-soluble marigold flower meal supplementation showed better performances concerning growth and skin coloration $(\mathrm{P}<0.05)$. This study showed that the $4 \%$ water-soluble marigold flower meal could be used as an alternative and useful pigmentation source for blue streak hap and pindani.

Keywords: Cichlidae; Marigold flower meal; Tagetes erecta; Coloration; Growth

(C) Ankara Üniversitesi Ziraat Fakültesi

\section{Introduction}

Ornamental fish are considered among the most popular pets worldwide, and also ornamental fish culture is known as one of the essential sectors of aquaculture. The aquarium fish production sector can be expressed as an important source for the gross national income of underdeveloped and developing countries (Yanar et al 2008). Thus, there is a steadily increasing in culture and trade of ornamental fish globally. The blue streak hap (Labidochromis caeruleus Fryer 1956) and pindani (Pseudotropheus socolofi Johnson 1974) are freshwater perciform fishes, belong Cichlidae family, and this family are described by a broad diversification of colors and color designs. The origins of both fishes are Lake Malawi in Africa. The blue streak hap and pindani are the most commercially valuable ornamental fish species and cultured all over the world (Ergün et al 2010). The market prices and acceptance of cultured aquarium fish are generally dependent on the vibrant colors. One of the main problems in cultured ornamental fish in the market is related to the inadequate coloration because the paleness of the color has a negative impact on the demand and market price. It's known that to achieve consumer acceptance and optimal price; cultured fish must be pigmented. For this reason, recent studies have been concentrated on coloration in the ornamental fish. The color of aquarium fish come from carotenoid pigments which are predominantly astaxanthin. Like other animals, also fish cannot biosynthesize carotenoids in their tissues. So, the pigmentation of fish generally depends on carotenoid content within the ingested food (Goodwin 1984; Moorhead \& Zeng 
2010; Ansarifard et al 2018; Pezeshk et al 2019). Fish species and size, feed content, colorant concentration in the ration, feeding rate, hereditary and environmental factors are also useful in the coloration of aquarium fish (Yeşilayer et al 2008). Several studies have been conducted to the use of carotenoids as pigments and also their effects on fish growth, maturation, reproduction and enhancing the immune system (Gupta et al 2007; Sinha \& Asimi 2007; Singh et al 2016; Singh \& Kumar 2016; Maiti et al 2017; Pezeshk et al 2019). In addition to coloring effects, the carotenoids are playing an essential role in animals such as pro-vitamin-A, antioxidant and immune-regulator. Also, they can be effective against the bacterial and fungal diseases (Shahidi et al 1998). Synthetic carotenoids are not only expensive but also it has limited usage in the feed formulations due to deteriorating effects on the environment (Gupta et al 2007). However, natural carotenoids are mainly herbal origin and generally derived from microalgae-based sources. The yellow corn, corn gluten meal, alfalfa flour and extract, red pepper flour and extract, marigold flour and extract, meadow grass and aquatic macrophytes are known as the conventional carotenoid-rich plant products (Kırkpınar \& Erkek 1999; Ezhil et al 2008; Velasco-Santamaría \& Corredor-Santamaría 2011). It is thought that natural carotenoid sources should be used to prevent potential harmful effects of synthetic carotenoids. Therefore, this study aimed to determine the effective dose of watersoluble marigold flower meal (Tagetes erecta) in blue streak hap (Labidochromis caeruleus) and pindani (Pseudotropheus socolofi) fry and to identify the comparative effects of synthetic carotenoid dosages on the growth performance and skin coloration.

\section{Material and Methods}

\subsection{Experimental design}

The study was carried out at Fisheries Research and Application Unit (FRAU, Faculty of Agriculture, Ankara University), Ankara, Turkey. In the two trials, 21 plastic tanks $(32 \times 25 \times 13 \mathrm{~cm}, 10 \mathrm{~L}$, Çankaya plastic, Istanbul, Turkey) were used. In this study, a total of 420 fish (210 blue streak hap, Labidochromis caeruleus and 210 pindani, Pseudotropheus socolofi) were obtained from the commercial producer (Ulus, Ankara) and used in the experiments. The stock rate for each tank was set to 10 fish $/ 10 \mathrm{~L}$ ( 5 blue streak hap, 5 pindani). In the experiments, the water temperature was kept constant at $27 \pm 1$ ${ }^{\circ} \mathrm{C}, 10 \%$ of the tank volume was siphoned, and the water was renewed daily. The water quality parameters such as $\mathrm{pH}$, dissolved oxygen (YSI ProPlus 20 multi-parameter), oxidation-reduction potential (American Marine USA Pinpoint ORP Monitor) were monitored daily, nitrite and ammonium were analyzed weekly with the standard method (Eaton et al 2005). Throughout the experiments, the variations of water quality parameters such as $\mathrm{pH}: 8.2 \pm 0.5$; DO: $7.8 \pm 0.4 \mathrm{mg} \mathrm{L}^{-1}$; ORP: $200 \pm 14 \mathrm{mV} ; \mathrm{NO}_{2}^{-}: 0.03 \pm 0.02 \mathrm{mg} \mathrm{L}^{-1} ; \mathrm{NH}_{4}^{+}: 0.06 \pm 0.03 \mathrm{mg} \mathrm{L}^{-1}$ were recorded.

\subsection{Feed additives, carotenoid analysis and feeding}

A commercial basal diet (500 $\mu \mathrm{m}$ trout, 55\% protein, Skretting Feed Production Inc. Mugla, Turkey) was used for the feeding of fish. Colorants, water-soluble marigold flower meal (M: from Tagetes erecta, Aksuvital Natural Products Ltd., Turkey) and synthetic carotenoid (SC) (Carophyll ${ }^{\circledR}$ pink, DSM Nutritional Products Ltd. Basel, Switzerland) were used as feed additives. The carotene content of the water-soluble marigold flower meal was calculated as $1040 \mathrm{mg} \mathrm{kg}^{-1}$ total carotenoid and synthetic carotene source of Carophyll@pink was $8 \%$ astaxanthin. To prevent the protein imbalance, fish meal (65\% protein) were added to the experimental feeds (Göçer et al 2006; Büyükçapar et al 2007; Yeşilayer et al 2011). Different doses of M (2, 4, 6, 8, 10, 12\% water-soluble marigold flower meal) and SC (50,100,150 mg kg-1 as astaxanthin per kg of feed) were dissolved in $10 \mathrm{~mL}$ of distilled water and added to the grounded basal feed $(100 \mathrm{~g})$ by the mixer. For the control feed, only dis tilled water was added. The prepared feed was dried in the incubator $\left(20\right.$ hours at $\left.35^{\circ} \mathrm{C}\right)$, ground and used after a 500 $\mu \mathrm{m}$ mesh sieve (stored in the refrigerator at $4 \pm 1{ }^{\circ} \mathrm{C}$ ). For the analysis of total carotenoids in water-soluble marigold flower flour and basal diet, $1 \mathrm{~g}$ of the sample was dissolved in $10 \mathrm{~mL}$ of acetone solution $(80 \%$; 80/20: Acetone/Distilled water). The concentration was diluted to $1 \mathrm{mg} \mathrm{mL}^{-1}$, and the absorbances were read at 450,645 and $663 \mathrm{~nm}$ on the Biobase BK-D560 Uv-Vis spectrophotometer (CI Scientific Pty Ltd., Australia) (Kocaçalışkan $\&$ Kadığlu 1990). The amount of these pigments and the supplementation dosages in experimental feeds were calculated as below (Table 1).

In the experiments, fish were fed ad libitum three times per day in the morning (08:00 am), at noon (12:30) and in the evening (06:00 pm). After one hour of feeding, faeces and feed wastes at the bottom of the tanks were syphoned. 
Table 1- The supplementation levels of the different experimental feeds

\begin{tabular}{lllll}
\hline Groups & $\begin{array}{l}\text { Ratio } \\
\left(\text { unit } \mathrm{kg}^{-1}\right)\end{array}$ & $\begin{array}{l}\text { Total carotenoids } \\
\left(\mathrm{mg} \mathrm{kg} \mathrm{g}^{-1}\right)\end{array}$ & $\begin{array}{l}\text { Astaxanthin } \\
\left(\mathrm{mg} \mathrm{kg}^{-1}\right)\end{array}$ & $\begin{array}{l}\text { Total pigment in feed } \\
\left(\mathrm{mg} \mathrm{kg}^{-1}\right)\end{array}$ \\
\hline Control & $0 \mathrm{~g}$ & 180 & NA & 180.0 \\
\hline M2 & $20 \mathrm{~g}$ & 20.8 & NA & $200.8(180+20.8)$ \\
M4 & $40 \mathrm{~g}$ & 41.6 & NA & $221.6(180+41.6)$ \\
M6 & $60 \mathrm{~g}$ & 62.4 & NA & $242.4(180+62.4)$ \\
M8 & $80 \mathrm{~g}$ & 83.2 & NA & $263.2(180+83.2)$ \\
M10 & $100 \mathrm{~g}$ & 104.0 & NA & $284.0(180+104)$ \\
M12 & $120 \mathrm{~g}$ & 124.8 & NA & $304.8(180+124.8)$ \\
\hline SC50 & $625 \mathrm{mg}$ & NA & 50 & $230.0(180+50)$ \\
SC100 & $1250 \mathrm{mg}$ & NA & 100 & $280.0(180+100)$ \\
SC150 & $1875 \mathrm{mg}$ & NA & 150 & $330.0(180+150)$ \\
\hline
\end{tabular}

Control, basal diet without supplementation (180 $\mathrm{mg} \mathrm{kg}^{-1}$ total carotenoid); M, water-soluble marigold flower meal (1040 mg kg-1 total carotenoid); M2, $2 \% \mathrm{M}$ (20.8 mg total carotenoid); M4, 4\% M (41.6 mg total carotenoid); M6, 6\% M (62.4 mg total carotenoid); M8, 8\% M (83.2 mg total carotenoid); M10, 10\% M (104 mg total carotenoid); M12, 12\% M (124.8 mg total carotenoid); SC, Synthetic carotene source (Carophyll ${ }^{\circledR}$ pink, DSM, Basel, Switzerland $80 \mathrm{~g}$ astaxanthin $\mathrm{kg}^{-1}$ ); SC50, $50 \mathrm{mg}$ astaxanthin; SC100, $100 \mathrm{mg}$ astaxanthin; SC150, 150 mg astaxanthin; NA, Not available. Chlorophyll a: (12.7 x A663 nm)-(2.69 x A645 nm), Chlorophyll b: (22.9 x A645 nm)-(4.68 x A663 nm), Total carotenoids: (4.07 x A450 nm)-((0.0435 x Chlorophyll a) $+(0.367 \times$ Chlorophyll b))

\subsection{Experiment I: The determination of the effective dosage for water-soluble marigold flower meal}

The aim of this experiment I was to determine the ideal dosage of the water-soluble marigold flower meal (M) added to the fish feed. In totally, 105 blue streak hap (initial weight: 0.246-0.262 g) and 105 pindani (initial weight: 0.274-0.294 g) were used. A total of 10 fish ( 5 blue streak hap and 5 pindani) were stocked in each plastic tank ( $10 \mathrm{~L})$. All trial were triplicated in 7 groups $(0,2,4,6,8,10,12 \% \mathrm{M})$ and tested for 30 days.

\subsection{Experiment II: Comparison of effective water-soluble marigold flower meal dosage and synthetic carotenoid}

The aim of the second trial was to compare the synthetic carotenoid (SC) with effective dosages of water-soluble marigold flower meal that have been taken from the results of the first trial. Experiment II was designed as 7 groups in triplicate. Except for the control group, fish were fed with diet contained a different ratio of $\mathrm{M}(2,4,8 \%)$ and SC (50, 100 and 150 $\mathrm{mg} \mathrm{kg}^{-1}$ ) during 30 days.

\subsection{Growth performance analysis}

All the fish ( 5 blue streak hap and 5 pindani in each replicate) were anaesthetized with a moderate dose of clove oil (Eugenol $5 \mathrm{mg} \mathrm{L}^{-1}$ ) to prevent possible damage during the measurements of live weight (W) and total length (TL) at the beginning and at the end of the trials. For both experiments survival rates (SR), growth parameters such as weight gain (WG), specific growth rate (SGR) and feed conversion ratio (FCR) were calculated by following formulas (Güroy et al 2012);

SR $($ survival rate $)=$ number of fish at the day 0 - Number of fish at the end of the period

WG (weight gain) = Wi-Wf (Wi, initial body weight; Wf, final body weight, $\mathrm{g}$ )

$\mathrm{SGR}($ specific growth rate $)=[(\ln \mathrm{Wf}-\ln \mathrm{Wi}) /$ days $] \times 100$

FCR (feed conversion ratio) $=$ Total feed given $(\mathrm{g}) /$ Total weight gain $(\mathrm{g})$

\subsection{Color analysis}

Color measurements were performed by Chroma Meter (the color system mode: International Commission on Illumination). The lightness $(L)$, redness $(a)$ and yellowness $(b)$ values of the groups were determined. The maximum number of the light in the system is 100 , corresponding to the white color; the lowest is 0 corresponding to black. The device (Time Group Inc. Beijing, China) was calibrated using the black and white inductor caps before measurements (CIE 1976; Güroy et al 2012). For the color analyses, three blue streak hap and three pindani from each replicate were randomly sampled and deeply anaesthetized with $10 \mathrm{mg} \mathrm{L}^{-1}$ Eugenol (clove oil). For the color measurement, the median portion of the lateral region of fish skin was chosen. Then, the color measurements were recorded for the statistical analysis. 


\subsection{Statistical analysis}

At the end of both the 30-days experiment periods data were analyzed by the SPSS 14 for Windows package program (SPSS Inc., Chicago, IL, USA). The differences of variance between the groups were performed by one-way ANOVA and DUNCAN post-hoc test (with a significance level of 0.05 , and the results were presented as mean \pm s.d).

\section{Results and Discussion}

\subsection{Experiment I: The determination of the effective dosage for water-soluble marigold flower meal}

\subsubsection{The growth and coloration parameters of blue streak hap}

At the beginning of experiment I; the initial weights of blue streak hap were varied between $0.246-0.262 \mathrm{~g}(\mathrm{P}>0.05)$. After 30 days, the best live final weight (Wf) with $0.580 \pm 0.018 \mathrm{~g}$ and also the final total length (TLf), the live weight gain (WG), and the specific growth rate (SGR) were taken from the M4 group (4\% water-soluble marigold flower meal) $(\mathrm{P}<0.05)$. It was determined that there was not a significant difference between the groups in terms of feed conversion ratio (FCR) $(\mathrm{P}>0.05)$. The highest FCR was obtained from the control group with $3.837 \pm 0.101 \%$, whereas the best (lowest) rate was achieved by the M4 group, with $2.580 \pm 0.657 \%(\mathrm{P}>0.05)$. The water-soluble marigold flower meal supplemented diets did not appear to have any effect on survival rates (SR). In experiment I for blue streak hap, there were no significant differences between the control group and the increasing doses of water-soluble marigold flower meal regarding the comparison of lightness $(L)$ values. Also, it was seen that the darkest $L$ value was obtained from M4 (4\% water-soluble marigold flower meal) group ( $\mathrm{P}>0.05)$. According to the comparison of the redness indicator, $a, \mathrm{M} 4$ group were found closest to red $(\mathrm{P}<0.05)$. The yellowness indicator $b$ presents the highest value for also the M4 group. However, no statistically significant differences were observed between the trial groups for yellowness indicator $b(\mathrm{P}>0.05)($ Table 2).

Table 2- Experiment I: Growth and coloration parameters of blue streak hap (L. caeruleus) fed with water-soluble marigold flower meal supplemented diets for 30 days

\begin{tabular}{lccccccc}
\hline \multicolumn{6}{l}{ Experiment I: blue streak hap } \\
\hline & Control $^{\mathrm{l}}$ & $M 2$ & $M 4$ & $M 6$ & $M 8$ & $M 10$ & $M 12$ \\
\hline Wi & $0.262 \pm 0.019^{\mathrm{a}}$ & $0.252 \pm 0.021^{\mathrm{a}}$ & $0.250 \pm 0.019^{\mathrm{a}}$ & $0.252 \pm 0.022^{\mathrm{a}}$ & $0.252 \pm 0.015^{\mathrm{a}}$ & $0.252 \pm 0.021^{\mathrm{a}}$ & $0.246 \pm 0.022^{\mathrm{a}}$ \\
Wf & $0.484 \pm 0.031^{\mathrm{a}}$ & $0.516 \pm 0.031^{\mathrm{a}}$ & $0.580 \pm 0.018^{\mathrm{b}}$ & $0.487 \pm 0.024^{\mathrm{a}}$ & $0.477 \pm 0.029^{\mathrm{a}}$ & $0.506 \pm 0.024^{\mathrm{a}}$ & $0.509 \pm 0.041^{\mathrm{a}}$ \\
TLi & $2.480 \pm 0.084^{\mathrm{a}}$ & $2.540 \pm 0.134^{\mathrm{a}}$ & $2.600 \pm 0.100^{\mathrm{a}}$ & $2.520 \pm 0.084^{\mathrm{a}}$ & $2.560 \pm 0.114^{\mathrm{a}}$ & $2.600 \pm 0.158^{\mathrm{a}}$ & $2.540 \pm 0.114^{\mathrm{a}}$ \\
TLf & $3.160 \pm 0.152^{\mathrm{a}}$ & $3.480 \pm 0.837^{\mathrm{bc}}$ & $3.600 \pm 0.187^{\mathrm{c}}$ & $3.380 \pm 0.164^{\mathrm{abc}}$ & $3.400 \pm 0.255^{\mathrm{bc}}$ & $3.440 \pm 0.152^{\mathrm{bc}}$ & $3.340 \pm 0.134^{\mathrm{ab}}$ \\
\hline WG & $0.222 \pm 0.001^{\mathrm{a}}$ & $0.266 \pm 0.018^{\mathrm{c}}$ & $0.328 \pm 0.010^{\mathrm{d}}$ & $0.232 \pm 0.017^{\mathrm{ab}}$ & $0.223 \pm 0.015^{\mathrm{a}}$ & $0.254 \pm 0.001^{\mathrm{bc}}$ & $0.262 \pm 0.010^{\mathrm{bc}}$ \\
SGR & $2.057 \pm 0.090^{\mathrm{a}}$ & $2.404 \pm 0.128^{\mathrm{b}}$ & $2.789 \pm 0.100^{\mathrm{c}}$ & $2.170 \pm 0.176^{\mathrm{ab}}$ & $2.106 \pm 0.164^{\mathrm{ab}}$ & $2.326 \pm 0.019^{\mathrm{ab}}$ & $2.411 \pm 0.101^{\mathrm{b}}$ \\
FCR & $3.837 \pm 0.101^{\mathrm{a}}$ & $3.232 \pm 1.116^{\mathrm{a}}$ & $2.580 \pm 0.657^{\mathrm{a}}$ & $3.630 \pm 0.770^{\mathrm{a}}$ & $3.784 \pm 0.822^{\mathrm{a}}$ & $3.347 \pm 0.953^{\mathrm{a}}$ & $3.233 \pm 0.791^{\mathrm{a}}$ \\
SR & $100 \pm 0.000^{\mathrm{a}}$ & $100 \pm 0.000^{\mathrm{a}}$ & $100 \pm 0.000^{\mathrm{a}}$ & $100 \pm 0.000^{\mathrm{a}}$ & $100 \pm 0.000^{\mathrm{a}}$ & $100 \pm 0.000^{\mathrm{a}}$ & $100 \pm 0.000^{\mathrm{a}}$ \\
\hline$L$ & $71.920 \pm 2.950^{\mathrm{a}}$ & $70.960 \pm 1.630^{\mathrm{a}}$ & $67.070 \pm 5.480^{\mathrm{a}}$ & $70.620 \pm 2.380^{\mathrm{a}}$ & $69.550 \pm 0.100^{\mathrm{a}}$ & $71.140 \pm 1.04^{\mathrm{a}}$ & $70.540 \pm 3.450^{\mathrm{a}}$ \\
$a$ & $-6.450 \pm 0.570^{\mathrm{a}}$ & $-5.600 \pm 0.390^{\mathrm{ab}}$ & $-3.730 \pm 0.850^{\mathrm{c}}$ & $-5.090 \pm 0.120^{\mathrm{b}}$ & $-4.420 \pm 0.460^{\mathrm{bc}}$ & $-4.590 \pm 0.88^{\mathrm{bc}}$ & $-4.930 \pm 0.740^{\mathrm{b}}$ \\
$b$ & $26.700 \pm 0.240^{\mathrm{a}}$ & $27.689 \pm 0.500^{\mathrm{a}}$ & $28.190 \pm 0.860^{\mathrm{a}}$ & $27.510 \pm 1.680^{\mathrm{a}}$ & $27.930 \pm 2.260^{\mathrm{a}}$ & $26.880 \pm 0.670^{\mathrm{a}}$ & $26.390 \pm 0.360^{\mathrm{a}}$ \\
\hline
\end{tabular}

${ }^{1}$, values (means \pm s.d.) in same line with different superscripts are significantly different $(\mathrm{P}<0.05)$. For the growth and for the color parameters five and three fish were measured from each replicates respectively. Control, basal diet without supplementation (180 mg kg ${ }^{-1}$ total carotenoid); $\mathrm{M}$, water-soluble marigold flower meal (1040 mg kg-1 total carotenoid); M2, 2\% M (20.8 mg total carotenoid); M4, 4\% M (41.6 mg total carotenoid); M6, 6\% M (62.4 $\mathrm{mg}$ total carotenoid); M8, 8\% M (83.2 mg total carotenoid); M10, 10\% M (104 mg total carotenoid); M12, $12 \% \mathrm{M}$ (124.8 mg total carotenoid); Wi (g), initial weight; Wf (g), final weight; TLi (cm), initial total length; TLf (cm), final total length; WG, wet weight gain; SGR, specific growth rate; FCR, feed conversion ratio; SR, survival rate; $L$, lightness (white $=100$, black $=0$ ); $a=$ redness (positive value $=$ red, negative value $=$ blue); $b=$ yellowness (positive value $=$ yellow, negative value $=$ blue)

\subsubsection{The growth and coloration parameters of pindani}

In experiment I; the best live weight gains of the pindani, which initial weight varied between $0.280-0.300 \mathrm{~g}$ were obtained from M4 group (4\% water-soluble marigold flower meal) at the end of 30 days. The best TLf, Wf, WG, and SGR results were obtained from the M4 group with statistically significant differences compared to the other groups $(\mathrm{P}<0.05)$. It was calculated that there were no significant differences between the groups in terms of FCR and SR (P>0.05). In experiment I, for pindani, there were statistically significant differences regarding the lightness $(L)$ values $(\mathrm{P}<0.05)$. The highest amount of $L$ was read from the control group, whereas the lowest $L$ values belong to the groups M4 and M10 (P<0.05). According to the redness $(a)$ results, we obtained the best color from M4 group, which closer to green $(\mathrm{P}<0.05)$. 
Considering the yellowness indicator $(b)$ values used as, although there were no differences between the groups, the closest value to blue was also obtained from M4 group (Table 3).

Table 3- Experiment I: Growth and coloration parameters of pindani (P. socolofi) fed with water-soluble marigold flower meal supplemented diets for 30 days

\begin{tabular}{|c|c|c|c|c|c|c|c|}
\hline \multicolumn{8}{|c|}{ Experiment I: pindani } \\
\hline & Control $^{I}$ & $M 2$ & M4 & M6 & $M 8$ & M10 & $M 12$ \\
\hline Wi & $0.280 \pm 0.021^{\mathrm{a}}$ & $0.290 \pm 0.016^{\mathrm{a}}$ & $0.300 \pm 0.019^{\mathrm{a}}$ & $0.280 \pm 0.024^{\mathrm{a}}$ & $0.280 \pm 0.010^{\mathrm{a}}$ & $0.290 \pm 0.013^{a}$ & $0.290 \pm 0.023^{\mathrm{a}}$ \\
\hline Wf & $0.512 \pm 0.016^{\mathrm{a}}$ & $0.554 \pm 0.015^{\mathrm{b}}$ & $0.582 \pm 0.022^{\mathrm{c}}$ & $0.532 \pm 0.023^{\mathrm{ab}}$ & $0.520 \pm 0.019^{a}$ & $0.530 \pm 0.014^{\mathrm{ab}}$ & $0.518 \pm 0.021^{\mathrm{a}}$ \\
\hline TLi & $2.540 \pm 0.167^{\mathrm{a}}$ & $2.600 \pm 0.141^{\mathrm{a}}$ & $2.600 \pm 0.158^{\mathrm{a}}$ & $2.640 \pm 0.152^{\mathrm{a}}$ & $2.600 \pm 0.100^{\mathrm{a}}$ & $2.640 \pm 0.114^{\mathrm{a}}$ & $2.600 \pm 0.158^{\mathrm{a}}$ \\
\hline TLf & $3.320 \pm 0.084^{\mathrm{a}}$ & $3.520 \pm 0.130^{\mathrm{ab}}$ & $3.620 \pm 0.205^{\mathrm{b}}$ & $3.500 \pm 0.122^{\mathrm{ab}}$ & $3.460 \pm 0.167^{\mathrm{ab}}$ & $3.480 \pm 0.148^{\mathrm{ab}}$ & $3.440 \pm 0.089^{\mathrm{ab}}$ \\
\hline WG & $0.233 \pm 0.003^{\mathrm{a}}$ & $0.264 \pm 0.001^{\mathrm{c}}$ & $0.279 \pm 0.06^{\mathrm{d}}$ & $0.248 \pm 0.003^{\mathrm{b}}$ & $0.240 \pm 0.000^{\mathrm{ab}}$ & $0.238 \pm 0.002^{\mathrm{a}}$ & $0.233 \pm 0.004^{\mathrm{a}}$ \\
\hline SGR & $2.020 \pm 0.055^{\mathrm{ab}}$ & $2.154 \pm 0.025^{\mathrm{bc}}$ & $2.184 \pm 0.021^{\mathrm{c}}$ & $2.75 \pm 0.155^{\mathrm{abc}}$ & $2.064 \pm 0.000^{\mathrm{abc}}$ & $1.987 \pm 0.003^{\mathrm{a}}$ & $1.980 \pm 0.002^{\mathrm{a}}$ \\
\hline FCR & $3.664 \pm 1.090^{\mathrm{a}}$ & $3.220 \pm 0.925^{\mathrm{a}}$ & $3.036 \pm 0.797^{\mathrm{a}}$ & $3.428 \pm 0.922^{\mathrm{a}}$ & $3.542 \pm 1.002^{\mathrm{a}}$ & $3.572 \pm 1.044^{\mathrm{a}}$ & $3.664 \pm 0.759^{a}$ \\
\hline SR & $100 \pm 0.000^{\mathrm{a}}$ & $100 \pm 0.000^{\mathrm{a}}$ & $100 \pm 0.000^{\mathrm{a}}$ & $100 \pm 0.000^{\mathrm{a}}$ & $100 \pm 0.000^{\mathrm{a}}$ & $100 \pm 0.000^{\mathrm{a}}$ & $100 \pm 0.000^{\mathrm{a}}$ \\
\hline$L$ & $78.450 \pm 01.340^{b}$ & $75.680 \pm 2.060^{\mathrm{ab}}$ & $72.160 \pm 1.47^{\mathrm{a}}$ & $75.300 \pm 0.400^{\mathrm{ab}}$ & $75.750 \pm 1.190^{\mathrm{ab}}$ & $73.700 \pm 3.190^{\mathrm{a}}$ & $75.300 \pm 4.240^{\mathrm{ab}}$ \\
\hline$a$ & $-6.000 \pm 0.2800^{\mathrm{b}}$ & $-6.520 \pm 0.130^{a b}$ & $-6.960 \pm 0.270^{\mathrm{a}}$ & $-5.830 \pm 0.250^{\mathrm{b}}$ & $-6.480 \pm 0.460^{a b}$ & $-6.300 \pm 0.850^{\mathrm{ab}}$ & $-6.430 \pm 0.250^{a b}$ \\
\hline$b$ & $-1.720 \pm 0.3700^{\mathrm{a}}$ & $-1.700 \pm 0.330^{\mathrm{a}}$ & $-1.990 \pm 0.130^{\mathrm{a}}$ & $-1.950 \pm 0.160^{a}$ & $-1.570 \pm 0.300^{\mathrm{a}}$ & $-1.550 \pm 0.100^{\mathrm{a}}$ & $-1.640 \pm 0.400^{\mathrm{a}}$ \\
\hline
\end{tabular}

${ }^{1}$, values (means \pm s.d.) in same line with different superscripts are significantly different $(\mathrm{P}<0.05)$. For the growth and for the color parameters five and three fish were measured from each replicates respectively; Control, basal diet without supplementation (180 mg kg-1 total carotenoid); $\mathrm{M}$, water-soluble marigold flower meal (1040 mg kg ${ }^{-1}$ total carotenoid); M2, 2\% M (20.8 mg total carotenoid); M4, 4\% M (41.6 mg total carotenoid); M6, 6\% M (62.4 $\mathrm{mg}$ total carotenoid); M8, 8\% M (83.2 mg total carotenoid); M10, 10\% M (104 mg total carotenoid); M12, $12 \%$ M (124.8 mg total carotenoid); Wi (g), initial weight, Wf (g), final weight; TLi (cm), initial total length; TLf $(\mathrm{cm})$, final total length; WG, wet weight gain; SGR, specific growth rate; FCR, feed conversion ratio; SR, survival rate; $L$, lightness (white $=100$, black $=0$ ); $a=$ redness (positive value $=$ red, negative value $=$ blue); $b=$ yellowness (positive value $=$ yellow, negative value $=$ blue $)$

\subsection{Experiment II: Effects of different levels of water-soluble marigold flower meal and synthetic carotenoid}

\subsubsection{The growth and coloration parameters of blue streak hap}

In experiment II; the blue streak hap (0.274-0.294 g), were fed with different levels of water-soluble marigold flower meal (M) and synthetic carotenoid (SC) during 30 days. We obtained the best Wf and TLf from M4 group, which was significantly different compared to the other groups $(\mathrm{P}<0.05)$. However, there was not a significant difference between the groups in terms of SGR, FCR, and SR $(\mathrm{P}>0.05)$. At the end of the 30 days, the difference concerning lightness $(L)$, redness $(a)$ and yellowness $(b)$ values between the groups was not statically significant $(\mathrm{P}>0.05)($ Table 4$)$.

Table 4- Experiment II: Growth and coloration parameters of blue streak hap (L. caeruleus) fed with water-soluble marigold flower meal and synthetic carotenoid supplemented diets for 30 days

\begin{tabular}{lccccccc}
\hline \multicolumn{6}{l}{ Experiment II: blue streak hap } \\
\hline & Control $^{l}$ & $M 2$ & $M 4$ & $M 8$ & $S C 50$ & $S C 100$ & $S C 150$ \\
\hline Wi & $0.274 \pm 0.017^{\mathrm{a}}$ & $0.290 \pm 0.012^{\mathrm{a}}$ & $0.292 \pm 0.019^{\mathrm{a}}$ & $0.288 \pm 0.018^{\mathrm{a}}$ & $0.294 \pm 0.009^{\mathrm{a}}$ & $0.282 \pm 0.009^{\mathrm{a}}$ & $0.290 \pm 0.016^{\mathrm{a}}$ \\
Wf & $0.576 \pm 0.009^{\mathrm{a}}$ & $0.610 \pm 0.016^{\mathrm{bc}}$ & $0.638 \pm 0.008^{\mathrm{d}}$ & $0.596 \pm 0.011^{\mathrm{b}}$ & $0.620 \pm 0.014^{\mathrm{cd}}$ & $0.600 \pm 0.016^{\mathrm{bc}}$ & $0.610 \pm 0.021^{\mathrm{bc}}$ \\
TLi & $2.640 \pm 0.114^{\mathrm{a}}$ & $2.560 \pm 0.152^{\mathrm{a}}$ & $2.540 \pm 0.114^{\mathrm{a}}$ & $2.580 \pm 0.179^{\mathrm{a}}$ & $2.480 \pm 0.148^{\mathrm{a}}$ & $2.580 \pm 0.164^{\mathrm{a}}$ & $2.540 \pm 0.167^{\mathrm{a}}$ \\
TLf & $4.120 \pm 0.084^{\mathrm{ab}}$ & $4.180 \pm 0.130^{\mathrm{ab}}$ & $4.280 \pm 0.084^{\mathrm{b}}$ & $4.100 \pm 0.141^{\mathrm{a}}$ & $4.160 \pm 0.055^{\mathrm{ab}}$ & $4.180 \pm 0.148^{\mathrm{ab}}$ & $4.100 \pm 0.158^{\mathrm{a}}$ \\
\hline WG & $0.302 \pm 0.002^{\mathrm{a}}$ & $0.319 \pm 0.006^{\mathrm{a}}$ & $0.348 \pm 0.011^{\mathrm{b}}$ & $0.307 \pm 0.009^{\mathrm{a}}$ & $0.327 \pm 0.005^{\mathrm{ab}}$ & $0.321 \pm 0.020^{\mathrm{ab}}$ & $0.322 \pm 0.012^{\mathrm{ab}}$ \\
SGR & $2.469 \pm 0.059^{\mathrm{a}}$ & $2.474 \pm 0.032^{\mathrm{a}}$ & $2.628 \pm 0.144^{\mathrm{a}}$ & $2.415 \pm 0.067^{\mathrm{a}}$ & $2.495 \pm 0.054^{\mathrm{a}}$ & $2.540 \pm 0.163^{\mathrm{a}}$ & $2.482 \pm 0.029^{\mathrm{a}}$ \\
FCR & $2.815 \pm 0.775^{\mathrm{a}}$ & $2.657 \pm 0.704^{\mathrm{a}}$ & $2.458 \pm 0.767^{\mathrm{a}}$ & $2.761 \pm 0.699^{\mathrm{a}}$ & $2.601 \pm 0.774^{\mathrm{a}}$ & $2.678 \pm 0.917^{\mathrm{a}}$ & $2.658 \pm 0.845^{\mathrm{a}}$ \\
SR & $100 \pm 0.00^{\mathrm{a}}$ & $100 \pm 0.000^{\mathrm{a}}$ & $100 \pm 0.000^{\mathrm{a}}$ & $100 \pm 0.000^{\mathrm{a}}$ & $100 \pm 0.000^{\mathrm{a}}$ & $100 \pm 0.000^{\mathrm{a}}$ & $100 \pm 0.000^{\mathrm{a}}$ \\
\hline$L$ & $71.920 \pm 2.950^{\mathrm{a}}$ & $70.960 \pm 1.630^{\mathrm{a}}$ & $67.070 \pm 5.480^{\mathrm{a}}$ & $70.620 \pm 2.380^{\mathrm{a}}$ & $69.550 \pm 0.100^{\mathrm{a}}$ & $71.140 \pm 1.040^{\mathrm{a}}$ & $70.540 \pm 3.450^{\mathrm{a}}$ \\
$a$ & $-6.450 \pm 0.570^{\mathrm{a}}$ & $-5.600 \pm 0.390^{\mathrm{ab}}$ & $-3.730 \pm 0.85^{\mathrm{c}}$ & $-5.090 \pm 0.12^{\mathrm{b}}$ & $-4.420 \pm 0.460^{\mathrm{bc}}$ & $-4.590 \pm 0.880^{\mathrm{bc}}$ & $-4.930 \pm 0.740^{\mathrm{b}}$ \\
$b$ & $26.700 \pm 0.240^{\mathrm{a}}$ & $27.689 \pm 0.500^{\mathrm{a}}$ & $28.190 \pm 0.860^{\mathrm{a}}$ & $27.510 \pm 1.680^{\mathrm{a}}$ & $27.930 \pm 2.260^{\mathrm{a}}$ & $26.880 \pm 0.670^{\mathrm{a}}$ & $26.390 \pm 0.360^{\mathrm{a}}$ \\
\hline
\end{tabular}

${ }^{1}$, values (means \pm s.d.) in same line with different superscripts are significantly different $(\mathrm{P}<0.05)$. For the growth and for the color parameters five and three fish were measured from each replicates respectively; Control, basal diet without supplementation $\left(180 \mathrm{mg} \mathrm{kg}^{-1}\right.$ total carotenoid); $\mathrm{M}$, water-soluble marigold flower meal (1040 mg kg-1 total carotenoid); M2, 2\% M (20.8 mg total carotenoid); M4, 4\% M (41.6 mg total carotenoid); M8, 8\% M (83.2

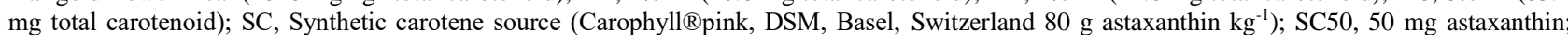
SC100, $100 \mathrm{mg}$ astaxanthin; SC150, $150 \mathrm{mg}$ astaxanthin; Wi (g), initial weight; Wf (g), final weight; TLi (cm), initial total length; TLf (cm), final total length; WG, wet weight gain; SGR, specific growth rate; FCR, feed conversion ratio; SR, survival rate; $L$, lightness (white=100, black=0); $a=$ redness (positive value $=$ red, negative value $=$ blue $) ; b=$ yellowness $($ positive value $=$ yellow, negative value $=$ blue $)$ 


\subsubsection{The growth and coloration parameters of pindani}

During 30 days, pindani (0.286-0.294 g), were fed with 2, 4 and 8\% rates of M. In experiment II; this natural colorant M was compared to a SC (50, 100, $150 \mathrm{mg} \mathrm{SC}$ feed $\left.\mathrm{kg}^{-1}\right)$. The best Wf and WG were obtained from M4 group (4\% M) $(\mathrm{P}<0.05)$. It was determined that there were no significant differences between the groups regarding TLf, SGR, FCR, and $\mathrm{SR}(\mathrm{P}>0.05)$. The highest value of lightness $(L)$ was measured from group control. In contrast, the lowest $L$ value belongs to the groups SC50 $(\mathrm{P}<0.05)$. According to the results given by the redness $(a)$, the lowest value (nearest to green) was read from group SC50 (-8.920 \pm 0.150$)$, the highest $a$ value was taken from the control group, and the difference between the groups was statistically significant $(\mathrm{P}<0.05)$. Concerning the yellowness $(b)$, it found its lower value (closest to blue color) in group SC50 and a statistically significant difference between the groups was determined $(\mathrm{P}<0.05)($ Table 5).

Table 5- Experiment II: Growth and coloration parameters of pindani (P. socolofi) fed with water-soluble marigold flower meal and synthetic carotenoid supplemented diets for 30 days

\begin{tabular}{|c|c|c|c|c|c|c|c|}
\hline \multicolumn{8}{|c|}{ Experiment II: pinhandi } \\
\hline & Control & $M 2$ & M4 & M8 & $S C 50$ & $S C 100$ & $S C 150$ \\
\hline$\overline{\mathrm{Wi}}$ & $0.290 \pm 0.010^{\mathrm{a}}$ & $0.286 \pm 0.013^{a}$ & $0.286 \pm 0.011^{\mathrm{a}}$ & $0.294 \pm 0.013^{\mathrm{a}}$ & $0.292 \pm 0.008^{a}$ & $0.292 \pm 0.013^{\mathrm{a}}$ & $0.294 \pm 0.018^{\mathrm{a}}$ \\
\hline Wf & $0.608 \pm 0.008^{\mathrm{ab}}$ & $0.618 \pm 0.037^{\mathrm{ab}}$ & $0.632 \pm 0.016^{\mathrm{b}}$ & $0.612 \pm 0.019^{\mathrm{ab}}$ & $0.606 \pm 0.009^{\mathrm{ab}}$ & $0.608 \pm 0.011^{\mathrm{ab}}$ & $0.604 \pm 0.011^{\mathrm{a}}$ \\
\hline TLi & $2.600 \pm 0.158^{\mathrm{a}}$ & $2.620 \pm 0.130^{\mathrm{a}}$ & $2.560 \pm 0.114^{\mathrm{a}}$ & $2.540 \pm 0.114^{\mathrm{a}}$ & $2.560 \pm 0.182^{\mathrm{a}}$ & $2.540 \pm 0.114^{\mathrm{a}}$ & $2.640 \pm 0.114^{\mathrm{a}}$ \\
\hline TLf & $3.880 \pm 0.164^{\mathrm{a}}$ & $4.000 \pm 0.173^{\mathrm{a}}$ & $4.000 \pm 0.187^{\mathrm{a}}$ & $3.880 \pm 0.164^{\mathrm{a}}$ & $3.860 \pm 0.182^{\mathrm{a}}$ & $3.880 \pm 0.164^{\mathrm{a}}$ & $3.940 \pm 0.134^{\mathrm{a}}$ \\
\hline$\overline{\mathrm{WG}}$ & $0.317 \pm 0.009^{\mathrm{a}}$ & $0.332 \pm 0.020^{\mathrm{ab}}$ & $0.349 \pm 0.020^{\mathrm{b}}$ & $0.318 \pm 0.002^{\mathrm{a}}$ & $0.313 \pm 0.005^{\mathrm{a}}$ & $0.316 \pm 0.001^{\mathrm{a}}$ & $0.311 \pm 0.007^{\mathrm{a}}$ \\
\hline SGR & $2.456 \pm 0.087^{\mathrm{a}}$ & $2.541 \pm 0.210^{\mathrm{a}}$ & $2.651 \pm 0.172^{\mathrm{a}}$ & $2.436 \pm 0.063^{\mathrm{a}}$ & $2.427 \pm 0.047^{\mathrm{a}}$ & $2.441 \pm 0.027^{\mathrm{a}}$ & $2.441 \pm 0.060^{\mathrm{a}}$ \\
\hline FCR & $2.674 \pm 0.680^{\mathrm{a}}$ & $2.565 \pm 0.574^{\mathrm{a}}$ & $2.419 \pm 0.550^{\mathrm{a}}$ & $2.673 \pm 0.775^{\mathrm{a}}$ & $2.707 \pm 0.727^{\mathrm{a}}$ & $2.690 \pm 0.751^{\mathrm{a}}$ & $2.742 \pm 0.826^{\mathrm{a}}$ \\
\hline SR & $100 \pm 0.000^{\mathrm{a}}$ & $100 \pm 0.00^{\mathrm{a}}$ & $100 \pm 0.00^{\mathrm{a}}$ & $100 \pm 0.00^{\mathrm{a}}$ & $100 \pm 0.00^{\mathrm{a}}$ & $100 \pm 0.00^{\mathrm{a}}$ & $100 \pm 0.00^{\mathrm{a}}$ \\
\hline$L$ & $77.750 \pm 0.610^{\mathrm{d}}$ & $73.320 \pm 3.480^{\mathrm{bc}}$ & $70.900 \pm 2.710^{b}$ & $76.870 \pm 2.780^{\mathrm{cd}}$ & $65.620 \pm 1.580^{\mathrm{a}}$ & $70.210 \pm 1.140^{\mathrm{b}}$ & $71.170 \pm 0.360^{\mathrm{b}}$ \\
\hline$a$ & $-6.230 \pm 0.080^{\mathrm{e}}$ & $-6.490 \pm 0.660^{\mathrm{de}}$ & $-7.920 \pm 0.190^{\mathrm{b}}$ & $-6.980 \pm 0.160^{\mathrm{cd}}$ & $-8.920 \pm 0.150^{\mathrm{a}}$ & $-7.550 \pm 0.420^{\mathrm{bc}}$ & $-7.470 \pm 0.430^{b c}$ \\
\hline$b$ & $-1.440 \pm 0.300^{\mathrm{e}}$ & $-1.890 \pm 0.170^{\mathrm{de}}$ & $-2.140 \pm 0.140^{\mathrm{cd}}$ & $-2.010 \pm 0.100^{\mathrm{cd}}$ & $-3.260 \pm 0.460^{\mathrm{a}}$ & $-2.440 \pm 0.330^{b c}$ & $-2.640 \pm 0.220^{\mathrm{b}}$ \\
\hline
\end{tabular}

${ }^{1}$, values (means \pm s.d.) in same line with different superscripts are significantly different $(\mathrm{P}<0.05)$. For the growth and for the color parameters five and three fish were measured from each replicates respectively; Control, basal diet without supplementation (180 mg kg-1 total carotenoid); $\mathrm{M}$, water-soluble marigold flower meal (1040 mg kg-1 total carotenoid); M2, 2\% M (20.8 mg total carotenoid); M4, 4\% M (41.6 mg total carotenoid); M8, 8\% M (83.2

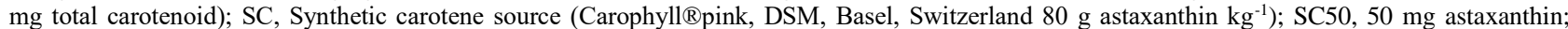
SC100, 100 mg astaxanthin; SC150, $150 \mathrm{mg}$ astaxanthin; Wi (g), initial weight; Wf (g), final weight; TLi (cm), initial total length; TLf (cm), final total length; WG, wet weight gain; SGR, specific growth rate; FCR, feed conversion ratio; SR, survival rate; L, lightness $($ white $=100$, black=0); a = redness (positive value $=$ red, negative value $=$ blue $) ; b=$ yellowness $($ positive value $=$ yellow, negative value $=b l u e)$.

Many aquatic organisms take natural carotenoids through their food for pigmentation of skin and muscle. The coloration of fish mainly depends on several factors such as carotenoid source and chemical structure, the lipid content of the feed, fish species and environmental conditions (Harpaz \& Padowicz 2007; Yanar et al 2007; Yanar et al 2008; Del Villar-Martínez et al 2013; Swian et al 2014; Kumar et al 2017). In aquaculture applications, the supplementation of nutritional carotenoid is essential for skin and meat pigmentation. Since these pigment substances cannot be synthesized by fish. As it is known that the most important criteria determining the market value of aquarium fish is the color viability of the skin. The studies carried out on natural and artificial pigment sources as a feed additive for different culture fish species showed that the marigold and synthetic carotenoids provided coloration and improved the growth parameters (Büyükçapar et al 2007; Moorhead \& Zeng 2010; Ansarifard et al 2018; Pezeshk et al 2019). Many studies in the literature have no adverse effects on the survival rate of natural carotenoids and in general terms, fish and crustaceans fed with diets containing carotenoids exhibit a higher survival rate (Ako et al 2000; Moorhead \& Zeng 2010). It has been reported that Pacific white shrimp (Litopenaeus vannamei) fed with $350 \mathrm{mg} \mathrm{kg}^{-1}$ marigold-supplemented diet for five weeks and achieved a better survival rate compared to the control group (Arredondo-Figueroa et al 1999). There are also reported a better survival rate without statistical significance for Koi, Cyprinius carpio fed with marigold oleoresin additive diet (Swian et al 2014) and goldfish, Carassius auratus fed with Spirulina supplemented food (Kumar et al 2017). The current study results showed that the non-negative effect of carotenoid supplementation on survival rate for tested cichlids.

In the present study, according to the experiment I, results showed that the low dosages (M2, M4 and M6) watersoluble marigold flower meal supplemented groups were significantly improved regarding final mean weight and SGR values compared to the control group $(\mathrm{P}<0.05)$. It can be claimed that at the level of $4 \%$ water-soluble marigold flower meal supplemented group showed better growth performance than other groups for experiment II. As shown in the overall data evaluation; in the first and second experiment, the best final live weight and length gains were also found in the M4 group for both fish species. This study result was in parallel with the report that effects of carotenoids on the growth rates of Atlantic salmon, Salmo salar fry (Christiansen et al 1995), rainbow trout, Oncorhynchus mykiss (De La Mora et al 
2006), shrimp, Litopenaeus vannamei (Ponce-Palafox et al 2006) goldfish, Carassius auratus (Sinha \& Asimi 2007), and certain freshwater ornamental fish species (Ako et al 2000; Velasco-Santamaría \& Corredor-Santamaría 2011).

It has been reported that natural carotenoids can be used in fish for promoting the skin coloration such as dwarf cichlid, Microgeophagus ramirezi (Harpaz \& Padowicz 2007), red swordtail, Xiphophorus helleri (Ezhil et al 2008), clown anemonefish, Amphiprion ocellaris (Ramamoorthy et al 2010), yellow tail cichlid, Pseudotropheus acei (Güroy et al 2012), goldfish, Carassius auratus (Del Villar-Martínez et al 2013; Kumar et al 2017).

In the first experiment, regarding the comparison of lightness $(L)$ value for blue steak hap, there were no significant differences between the control group and the increasing doses of water-soluble marigold flower meal groups $(\mathrm{P}>0.05)$ (Table 1). However, for pindani, shown in Table 2, $4 \%$ and $10 \%$ water-soluble marigold flower meal supplemented groups were better than the control group in terms of the darkest $L$ values (lightness: white $=100$, black $=0)(\mathrm{P}<0.05)$. The redness (a) values from M4 group were found better than all groups for both cichlid fry $(\mathrm{P}<0.05)$. Besides, there were no significant differences between all groups in terms of yellowness $(b)$ value $(\mathrm{P}>0.05)$. When the results of the experiment I, were evaluated, it can be assumed that the $4 \%$ water-soluble marigold flower meal supplemented diet had a positive effect on the skin coloration. This situation can also be explained as an indication of the carotenoid intake or transfer to the tissues to reach saturation levels (Yanar et al 2008).

In experiment II, there were no differences between the M and SC groups regarding the lightness $(L)$, and yellowness (b) values of blue streak hap $(\mathrm{P}>0.05)$ except redness $(a)$ values. However, for pindani, the best color values were taken from SC50 group in terms of lightness $(L$ : lightness white $=100$, black $=0)$, redness $(a$ : positive value $=$ red, negative value $=$ blue) and yellowness values $(b$ : positive value $=$ yellow, negative value $=$ blue $)$, and this group followed by $4 \%$ watersoluble marigold flower meal supplemented group. It can be stated that using the $4 \%$ water-soluble marigold flower meal in the diet will improve the skin coloration of blue streak hap and pindani without any adverse effects on growth performance.

\section{Conclusions}

In conclusion, this study showed that the dietary supplementation of $4 \%$ water-soluble marigold flower meal as a natural carotenoid source could be used instead of the tested synthetic carotenoid, in cichlids, for the skin coloration, growth, and survival rate.

\section{Acknowledgements}

The authors would like to thank to Dr F. Sertel Secer, Dr Safak Dikmen, Dr Farah G. Aydin, and Research Assistant Nazlı Turkmen (Ankara University) for their help. The authors gratefully acknowledge Dr Gokben Ozbakıs Beceriklisoy, who is the Responsible Veterinarian of FRAU, Ankara University. This study was a part of the PhD thesis (with two supervisors) conducted by the first author, Nuran Cavdar. This research was supported by Akuamaks Ltd. (Rabat Str. 22/6 GOP, Cankaya, Ankara, TR) in the theme of contribution on the aquaculture sector. Conflict of interest: the authors declare that they have no conflict of interest. Ethical approval: the authors followed ethical approval, all applicable international, national, and/or institutional guidelines for the care and use of animals. The permission of the $\mathrm{PhD}$ thesis for the animal experiment (2016-25-208) was received on 21.12.2016 from Animal Experiments Local Ethics Committee of Ankara University.

\section{References}

Ako H, Tamaru C S, Asano L, Yuen B \& Yamamoto M (2000). Achieving natural coloration in fish under culture. UJNR Technical Report 28: 1-4

Ansarifard F, Rajabi Islami H, Shamsaie Mehrjan M \& Soltani M (2018). Effects of Arthrospir platensis on growth, skin color and digestive enzymes of Koi, Cyprinus carpio. Iranian Journal of Fisheries Sciences 17(2): 381-393

Arredondo-Figueroa J L, Ponce-Palafox J T \& Vernon-Carter E J (1999). Dose-Response to unesterified pigments of Aztec Marigold, Tagetes erecta, in the Pacific white shrimp, Litopenaeus vannamei, fed with various dietary concentrations of carotenoids. Crustacean Issues 12: 481-487

Büyükçapar H M, Yanar M \& Yanar Y (2007). Pigmentation of rainbow trout (Oncorhynchus mykiss) with carotenoids from marigold flower (Tagetes erecta) and red pepper (Capsicum annum). Turkish Journal of Veterinary and Animal Sciences 31(1): 7-12

Journal of Agricultural Sciences (Tarım Bilimleri Dergisi) 26 (2020) 307-315 
Christiansen R, Lie O \& Torrissen O J (1995). Growth \& survival of Atlantic salmon, Salmo salar L., fed different dietary levels of astaxanthin first-feeding fry. Aquaculture Nutrition 1: 189-198

CIE (1976). Official recommendations on uniform colour space, colour difference equations and metric colour terms. Suppl. No. 2 , Publication No. 15. Commission International de l'Eclairage, Paris

De La Mora G I, Arredondo-Figueroa J L, Ponce-Palafox J T, Barriga-Soca I D A \& Vernon-Carter J E (2006). Comparison of red chilli (Capsicum annuum) oleoresin and astaxanthin on rainbow trout (Oncorhyncus mykiss) fillet pigmentation. Aquaculture 258: 487-495

Del Villar-Martínez A A, Orbe-Rogel J C, Vanegas-Espinoza P E, Quintero-Gutiérrez A G \& Lara-Floreset M, (2013). The effect of marigold (Tagetes erecta) as natural carotenoid source for the pigmentation of goldfish (Carassius auratus L.). Research Journal of Fisheries and Hydrobiology 8(2): 31-37

Eaton A D, Clesceri L S, Greenberg A E, \& Franson M A H (2005). Standard methods for the examination of water and wastewater. American Public Health Association 21: 1600

Ergün S, Güroy D, Tekeşoğlu H, Güroy B, Çelik İ, Tekinay A A \& Bulut M (2010). Optimum dietary protein level for blue streak hap, Labidochromis caeruleus. Turkish Journal of Veterinary and Animal Sciences 10: 27-31

Ezhil J, Jeyanthi C \& Narayanan M (2008). Marigold as a carotenoid source on pigmentation and growth of red swordtail, Xiphophorus helleri. Turkish Journal of Fisheries and Aquatic Sciences 8(1): 99-101

Göçer M, Yanar M, Kumlu M \& Yanar Y (2006). The effect of red pepper, marigold flower, and synthetic astaxanthin on pigmentation, growth, and proximate composition of Penaeus semisulcatus. Turkish Journal of Veterinary and Animal Sciences 30(4): 359-365

Goodwin T W (1984). The Biochemistry of the Carotenoids, II. Animals. London: Chapman \& Hall p. 224

Gupta S K, Jha A K, Pal A K \& Venkateshwarlu G (2007). Use of natural carotenoids for pigmentation in fishes. Natural Product Radiance 6(1): 46-49

Güroy B, Şahin İ, Mantoğlu S \& Kayalı S (2012). Spirulina as a natural carotenoid source on growth, pigmentation and reproductive performance of yellow tail cichlid Pseudotropheus acei. Aquaculture International 20: 869-878

Harpaz S \& Padowicz D (2007). Color enhancement in the ornamental dwarf cichlid Microgeophagus ramirezi by addition of plant carotenoids to the fish diet. The Israeli Journal of Aquaculture-Bamidgeh 59(4): 195-200

Kocaçalışkan İ \& Kadığlu A (1990). Bitki fizyolojisi laboratuvar klavuzu. Atatürk Üniversitesi, Fen-Edebiyat Fakültesi Yayını, 119

Kırkpınar F \& Erkek R (1999). The effects of some natural and synthetic pigment materials on egg yolk pigmentation and production in yellow corn diets. Turkish Journal of Veterinary and Animal Sciences 23(1): 15-21

Kumar P A, Sudhakaran S, Mohan T C, Pamanna D, Kumar P R \& Shanthanna P (2017). Evaluation of colour enhance potential of three natural plant pigment sources (African tulip tree flower, red paprika, pomegranate peel) in goldfish (Carassius auratus). International Journal of Fisheries and Aquatic Studies 5(6): 47-51

Maiti M K, Bora D, Nandeesha T L, Sahoo S, Adarsh B K \& Kumar S (2017). Effect of dietary natural carotenoid sources on colour enhancement of koi carp, Cyprinus carpio L. International Journal of Fisheries and Aquatic Studies 5(4): 340-345

Moorhead J A \& Zeng C (2010). Development of captive breeding techniques for marine ornamental fish: a review. Reviews in Fisheries Science 18(4): 315-343

Pezeshk F, Babaei S, Abedian Kenari A, Hedayati M \& Naseri M (2019). The effect of supplementing diets with extracts derived from three different species of macroalgae on growth, thermal stress resistance, antioxidant enzyme activities and skin colour of electric yellow cichlid (Labidochromis caeruleus). Aquaculture Nutrition 25(2): 436-443

Ponce-Palafox J T, Arredondo-Figueroa J L \& Vernon-Carter E J (2006). Carotenoids from plants used in diets for the culture of the pacific white shrimp (Litopenaeus vannamei), Revista Mexicana De Ingenieria Quimica 5: 157-165

Ramamoorthy K, Bhuvaneswari S, Sankar G \& Sakkaravarthi K (2010). Proximate composition and carotenoid content of natural carotenoid sources and its colour enhancement on marine ornamental fish Amphiprion ocellaris (Cuveir, 1880). World Journal of Fish and Marine Sciences 2(6): 545-550 
Shahidi F, Metusalach A \& Brown J A (1998). Carotenoid pigments in seafood and aquaculture. Critical Reviews of Food Science and Nutrition 38: 1-67

Singh A P, Dinwiddie A, Mahalwar P, Schach U, Linker C, Irion U \& Nüsslein-Volhard C (2016). Pigment cell progenitors in zebrafish remain multipotent through metamorphosis. Developmental Cell 38(3): 316-330

Singh R N \& Kumar A (2016). Beetroot as a carotenoid source on growth and color development in red swordtail (Xiphophorus helleri) fish. Imperial Journal of Interdisciplinary Research 2(10): 637-642

Sinha A \& Asimi O A (2007). China rose (Hibiscus rosa sinensis) petals: A potent natural carotenoid source for goldfish (Carassius auratus L.). Aquaculture Resesearch 38: 1123-1128

Swian H S, Senapati S R, Meshram S J, Mishra R \& Murthy H S (2014). Effect of dietary supplementation of marigold oleoresin on growth, survival and total muscle carotenoid of koi carp, Cyprinus carpio L. J of Applied and Natural Science 6(2): 430-435

Velasco-Santamaría Y \& Corredor-Santamaría W (2011). Nutritional requirements of freshwater ornamental fish: a review. Revista MVZ Córdoba 16(2): 2458-2469

Yanar Y, Büyükçapar H M, Yanar M \& Göcer M (2007). Effect of carotenoids from red pepper and marigold flower on pigmentation, sensory properties and fatty acid composition of rainbow trout. Food Chemistry 100(1): 326-330

Yanar M, Erçen Z, Hunt A Ö \& Büyükçapar H M (2008). The Use of Alfalfa, Medicago sativa as a Natural Carotenoid Source in Diets of Goldfish, Carassius auratus. Aquaculture 284: 196-200

Yeşilayer N, Doğan G \& Erdem M (2008). The use of natural carotenoid sources in fish feed. Journal of Fisheries Sciences.com 2(3): 241-251

Yeşilayer N, Aral O, Karsli Z, Öz M, Karaçuha A \& Yağci F (2011). The effects of different carotenoid sources on skin pigmentation of Goldfish (Carassius auratus). The Israeli Journal of Aquaculture-Bamidgeh 63: 1-9 